\title{
Battle Staff Training System in Support of Force XXI Training Program: Methodology and Lessons Learned
}

Charles R. Andre, Richard L. Wampler, and George W. OIney BDM Federal, Inc.

\section{Armored Forces Research Unit \\ Barbara A. Black, Chief}

U.S. Army Research Institute for the Behavioral and Social Sciences 5001 Eisenhower Avenue, Alexandria, Virginia 22333-5600

Office, Deputy Chief of Staff for Personnel

Department of the Army

September 1997 